University of Nebraska - Lincoln

DigitalCommons@University of Nebraska - Lincoln

Agronomy \& Horticulture -- Faculty Publications

Agronomy and Horticulture Department

$9-1988$

independent Inheritance of Genes for Dhurrin and

Leucoanthocyanidin in a Sorghum Cross

Francis A. Haskins

University of Nebraska-Lincoln, fhaskins@neb.rr.com

Herman J. Gorz

United States Department of Agriculture

Follow this and additional works at: https://digitalcommons.unl.edu/agronomyfacpub

Part of the Plant Sciences Commons

Haskins, Francis A. and Gorz, Herman J., "independent Inheritance of Genes for Dhurrin and Leucoanthocyanidin in a Sorghum Cross" (1988). Agronomy \& Horticulture -- Faculty Publications. 260. https://digitalcommons.unl.edu/agronomyfacpub/260

This Article is brought to you for free and open access by the Agronomy and Horticulture Department at DigitalCommons@University of Nebraska - Lincoln. It has been accepted for inclusion in Agronomy \& Horticulture -Faculty Publications by an authorized administrator of DigitalCommons@University of Nebraska - Lincoln. 


\section{INDEPENDENT INHERITANCE OF GENES FOR DHURRIN AND LEUCOANTHOCYANIDIN IN A SORGHUM CROSS}

\author{
F. A. Haskins* and H. J. Gorz
}

\begin{abstract}
Flag leaves of KS8 sorghum [Sorghum bicolor (L.) Moench] are low in dhurrin [ $p$-hydroxy-(S)-mandelonitrile- $\beta$-D-glucoside] content and thus in hydrocyanic acid potential (HCN-p), and they contain little (if any) leucoanthocyanidin (LAC). Comparable leaves of 'Colman' sorghum are intermediate in HCN-p and high in LAC. This study was conducted to investigate the inheritance of HCN-p and LAC in crosses of KS8 $\times$ Colman. Flag leaves from field-grown plants of both parents; the $F_{1}, K S 8 \times$ Colman; the backcross, KS8 $\times\left(\right.$ KS8 $\times$ Colman); and the $F_{2}$, $($ KS8 $\times$ Colman $)$ selfed, were assayed for both HCN-p and LAC. Assays for HCN-p indicated that the backcross values provided a good fit to 1 intermediate: 1 low $\left(X^{2}=0.05, P=0.82\right)$ and $F_{2}$ results to 3 intermediate: 1 low $\left(X^{2}=\right.$ $0.96, P=0.33)$. For LAC, backcross results were 1 LAC $+: 1$ LAC $\left(X^{2}=0.20, P=0.65\right)$ and $F_{2}$ values were 3 LAC $+: 1 \mathrm{LAC}-$ (exact fit). Classification for both traits yielded good fits to 1:1:1:1 for the backcross $\left(X^{2}=0.30, P=0.96\right)$ and $9: 3: 3: 1$ for the $F_{2}\left(X^{2}=3.24, P\right.$ $=0.36$ ). These resuits indicated that the difference in HCN-p between Colman and KS8 depended primarily on a single gene, the difference in LAC depended largely on a separate single gene, and the HCN-p gene and the LAC gene were not linked.
\end{abstract}

A 1986 REPORT (1) indicated that a single gene difference was primarily responsible for the difference in dhurrin content (expressed as hydrocyanic acid potential, HCN-p) of mature leaves between KS8 (lowHCN-p) and N32 (high-HCN-p) lines of sorghum. Similarly, the large difference in flag-leaf leucoanthocyanidin (LAC) content between 'White Collier' $(\mathrm{LAC}-)$ and Colman (LAC+) sorghums depended largely on a single pair of genes (2). Both KS8 and N32 were $L A C-$, and the HCN-p values for flag leaves of both Colman and White Collier were intermediate between the values for KS8 and N32 (F.A. Haskins and H.J. Gorz, 1988, unpublished observations). Therefore, the crosses used in the previous studies were considered inappropriate for investigating the possible linkage of the HCN-p and LAC traits. The objective of the present study was to investigate the segregation of these two traits in a cross of KS8 (low-HCN-p, $\mathrm{LAC}-$ ) $\times$ Colman (intermediate-HCN-p, LAC + ).

\section{Materials and Methods}

Colman (male-fertile), AKS8 (cytoplasmic male-sterile), and BKS8 (male-fertile, sterility maintainer) sorghum plants were grown at the Agronomy Farm, Lincoln, NE, during the summer of 1985. The status of Colman with respect to fertility restoration was unknown; therefore, to ensure that malefertile $F_{1}$ plants would be produced, BKS8 plants were hand emasculated and pollinated with Colman pollen. In Novem-

F.A. Haskins, Dep. of Agronomy, and H.J. Gorz, USDA-ARS and Dep. of Agronomy, Nebraska Agric. Res. Div., Lincoln, NE 68583. Published as Paper no. 8484, Journal Series, Nebraska Agric. Res. Div. Research was conducted under Project no. 12-114.

Received 27 Nov. 1987. *Corresponding author.

Published in Crop Sci. 28:864-865 (1988) ber, 1985, the $F_{1}$ seed was sent to Puerto Rico (Tropical Agricultural Research Station, USDA-ARS, Mayaguez) where $F_{1}$ plants were self-pollinated to produce $F_{2}$ seed, and were also used as pollen parents in backcrosses to AKS8. AKS8 $X$ Colman crosses also were made during the summer of 1985 to obtain larger quantities of seed from which $F_{\text {, plants }}$ could be grown for sampling.

Plants of BKS8, Colman, the $F_{1}$ (AKS8 $\times$ Colman), the backcross [AKS8 $\times(B K S 8 \times$ Colman $)]$, and the $F_{2}$ [(BKS8 $\times$ Colman) selfed] were started in the greenhouse during the spring of 1986 and were transplanted to the Agronomy Farm on 29 May. Plants were placed $0.61 \mathrm{~m}$ apart in rows with a $0.76-\mathrm{m}$ spacing. The experiment was planted in four replications, with each replication including one 10-plant row of each parent and the $F_{1}$, two rows of the backcross, and five rows of the $F_{2}$. Thus, the experiment was designed to include 40 plants of each parent and the $F_{1}, 80$ backcross plants, and $200 \mathrm{~F}_{2}$ plants. Entries were assigned at random to the 10 rows in each replication. Insufficient plants of both parents and the $F_{1}$ were available for transplanting; therefore, seeded rows of BKS8, Colman and the $F_{1}$ were used in two, three, and one of the replications, respectively.

On 30 July, when panicles were emerging from most plants, the blade of the flag leaf was harvested from each plant. One $\mathrm{KS} 8$ and $21 \mathrm{~F}_{2}$ plants were not sufficiently advanced to allow positive identification of the flag leaf; for these plants, the blade of the youngest leaf with a visible collar was harvested. Midribs were removed from the leaf blades, and the remaining tissue was dried at 70 to $75^{\circ} \mathrm{C}$ overnight. The dry tissue was ground through a $1-\mathrm{mm}$ screen and stored in plastic vials at $-18{ }^{\circ} \mathrm{C}$ prior to extraction for assay.

Extraction and assay for HCN-p were conducted as described previously (1) except that dhurrin was hydrolyzed enzymatically rather than with $\mathrm{NaOH}$. The enzyme preparation was an extract made by soaking defatted almond meal (Sigma Chemical Co., St. Louis, MO) ${ }^{\prime}$ in distilled water $(8$ $\mathrm{mg} \mathrm{mL}^{-1}$ ) and filtering the suspension through Whatman no. 1 filter paper. To hydrolyze dhurrin, $1 \mathrm{~mL}$ of this filtrate was added to $1 \mathrm{~mL}$ of leaf extract, and the mixture was incubated in a parafilm-capped tube at room temperature for $1.25 \mathrm{~h}$. Following this incubation, $8 \mathrm{~mL}$ of $0.1 \mathrm{M} \mathrm{NaOH}$ was added, and a 1-mL portion of the resulting solution was assayed colorimetrically as described previously (1).

The procedure described by Haskins and Gorz (2) was used for extraction and assay of LAC. Absorbance at 540 $\mathrm{nm}$ was used as a measure of LAC content.

\section{Results and Discussion}

\section{Segregation for $H C N-p$}

Mean HCN-p values for KS8 and Colman were 29 and $135 \mathrm{mg} \mathrm{kg}^{-1}$, respectively, and standard errors were such that these means appeared to be well separated (Table 1). However, ranges in HCN-p for these two parents overlapped slightly, which caused some uncertainty in the classification of backcross and $F_{2}$ plants as either low (L) or intermediate (I) in $\mathrm{HCN}$ p. As shown in the table, with $50 \mathrm{mg} \mathrm{kg}^{-1}$ as the dividing line between the classes, only one of $37 \mathrm{KS} 8$ plants was classified as I-HCN-p and only two of 40 Colman plants were classified as L-HCN-p. With this dividing line, 41 of the backcross plants were I-HCN-

\footnotetext{
' Names of products are included for the benefit of the reader and do not imply endorsement or preferential treatment by the USDA or the Univ. of Nebraska.
} 
Table 1. Level of hydrocyanic acid potentiai (HCN-p) and leucoanthocyanidin (LAC, as measured by $\mathrm{A}_{540}$ ) in flag leaves of parental KS8 and Colman sorghum plants and of $F_{1}\left(A K S 8 \times\right.$ Colman), $B_{1}[A K S 8 \times(B K S 8 \times$ Colman $)]$, and $F_{2}[(B K S 8 \times C o l m a n)$ selfed $]$ plants derived from these parents.

\begin{tabular}{|c|c|c|c|c|c|c|c|c|c|c|}
\hline \multirow[b]{3}{*}{ Entry } & \multicolumn{5}{|c|}{ Phenotypic class ${ }^{\dagger}$} & \multirow{2}{*}{\multicolumn{2}{|c|}{$\mathrm{HCN}-\mathrm{p}$}} & \multirow{2}{*}{\multicolumn{2}{|c|}{$\mathrm{A}_{540}$}} & \multirow[b]{3}{*}{ Chi-square } \\
\hline & \multirow{2}{*}{$\begin{array}{l}\text { HCN-p: } \\
\text { LAC: }\end{array}$} & \multirow{2}{*}{$\begin{array}{l}\text { I } \\
+\end{array}$} & \multirow{2}{*}{1} & \multirow{2}{*}{$\begin{array}{l}\mathrm{L} \\
+\end{array}$} & \multirow{2}{*}{$\frac{\mathrm{L}}{-}$} & & & & & \\
\hline & & & & & & Mean $\pm \mathrm{SE}$ & Range & Mean $\pm \mathrm{SE}$ & Range & \\
\hline & & & & & & $\longrightarrow \mathrm{mg} \mathrm{k}$ & $\mathrm{wt}-$ & & & \\
\hline KS8 & & & 1 & & 36 & $29 \pm 2$ & $7-52$ & $0.005 \pm 0.0004$ & $0-0.010$ & \\
\hline Colman & & 38 & & 2 & & $135 \pm 13$ & $31-349$ & $1.33 \pm 0.05$ & $0.770-2.0$ & \\
\hline$F_{1}$ & & 36 & & 3 & & $86 \pm 6$ & $47-194$ & $0.51 \pm 0.02$ & $0.242-0.72$ & \\
\hline $\mathrm{BC}_{1}$ & & 22 & 19 & 20 & 19 & $\begin{array}{r}170 \pm 23 \\
222 \pm 37 \\
27 \pm 2 \\
30 \pm 3\end{array}$ & $\begin{array}{l}61-505 \\
51-751 \\
11-44 \\
10-48\end{array}$ & $\begin{array}{l}0.41 \pm 0.04 \\
0.006 \pm 0.001 \\
0.43 \pm 0.04 \\
0.006 \pm 0.001\end{array}$ & $\begin{array}{c}0.090-0.80 \\
0-0.017 \\
0.117-0.86 \\
0-0.013\end{array}$ & $\begin{array}{c}\text { for } 1: 1: 1: 1 \\
0.30 \\
(P=0.96)\end{array}$ \\
\hline $\mathrm{F}_{2}$ & & 104 & 40 & 46 & 10 & $\begin{array}{r}204 \pm 19 \\
332 \pm 40 \\
31 \pm 2 \\
25 \pm 4\end{array}$ & $\begin{array}{c}52-1178 \\
52-1247 \\
4-50 \\
7-38\end{array}$ & $\begin{array}{ll}0.64 & \pm 0.04 \\
0.007 & \pm 0.001 \\
0.63 & \pm 0.05 \\
0.008 & \pm 0.001\end{array}$ & $\begin{array}{c}0.063-1.80 \\
0-0.017 \\
0.034-1.40 \\
0.001-0.014\end{array}$ & $\begin{array}{c}\text { for } 9: 3: 3: 1 \\
3.24 \\
(P=0.36)\end{array}$ \\
\hline
\end{tabular}

† Class limits: Intermediate (I) HCN-p-values $>50 \mathrm{mg} \mathrm{kg}^{-1}$; Low (L) HCN-p-values $\leq 50 \mathrm{mg} \mathrm{kg}^{-1} ; \mathrm{LAC}+-\mathrm{A}_{540}>0.02 ; \mathrm{LAC}--\mathrm{A}_{540} \leq 0.02$.

p and 39 were L-HCN-p; and in the $F_{2}, 144$ plants were I-HCN-p and 56 were L-HCN-p. Chi-square values for fits to $1: 1$ and $3: 1$ ratios were $0.05(P=0.82)$ and $0.96(P=0.33)$, respectively. These data support the hypothesis that a single gene difference had a major role in determining HCN-p in crosses between KS8 and Colman. The possible relationship of this gene to the gene with a major influence on HCN-p in the KS8 $\times \mathrm{N} 32$ cross (1) was not investigated.

\section{Segregation for $L A C$}

The difference in LAC between KS8 and Colman plants was more distinct than the difference in $\mathrm{HCN}$ p. The lowest $\mathbf{A}_{540}$ value observed for Colman was about 70 times as large as the highest value for KS8 (Table 1). An $A_{540}$ value of 0.02 was used to separate LAC - and LAC + classes. The observed backcross segregation was $42 \mathrm{LAC}+: 38 \mathrm{LAC}-$, and the $\mathrm{F}_{2}$ segregation was $150 \mathrm{LAC}+: 50 \mathrm{LAC}-$. The former ratio was a good fit to $1: 1\left(X^{2}=0.20, P=0.65\right)$, and the latter an exact fit to a 3:1 ratio, indicating that with respect to LAC, KS8 and Colman differed primarily by a single gene. In preliminary qualitative tests, $F_{1}$ plants resulting from the cross $\mathrm{N} 32 \times$ White Collier and also from $(\mathrm{KS} 8 \times \mathrm{N} 32) \times$ White Collier were uniformly LAC - (F.A. Haskins and H.J. Gorz, 1988, unpublished observations). Thus, KS8, N32, and White Collier probably were genetically similar with respect to their inability to form LAC.

\section{Independent Segregation for $H C N-p$ and $L A C$}

Classification of the 80 backcross and $200 \mathrm{~F}_{2}$ plants for both HCN-p and LAC provided good fits to $1: 1: 1: 1$ and 9:3:3:1 ratios, respectively (Table 1 ). Thus, the two traits were inherited independently in the cross of KS8 $\times$ Colman.

In a previous study (3), assay of $F_{2}$ plants from a cross of Colman $\times$ White Collier for both HCN-p and LAC revealed a significant but rather weak negative association between the two traits $\left[r=-0.42^{* *}\right.$ (at the 0.01 probability level), $n=119$ ]. The possibility was suggested that this relationship might have resulted from linkage between the major gene for LAC and one or more genes for HCN-p. Alternatively, it was suggested that the negative association might have arisen from competition for common precursors of dhurrin and LAC, both of which are aromatic compounds. The backcross and $F_{2}$ ratios obtained in the present study indicated that in the KS8 $\times$ Colman cross, major genes for HCN-p and LAC were not linked. Furthermore, if such linkage existed, a positive association between HCN-p and LAC in the backcross and $F_{2}$ generations would be expected, because the LHCN-p and LAC - traits came from one parent and I-HCN-p and LAC + traits from the other parent in the cross. This positive relationship was not observed; the relationship between HCN-p and LAC in the backcross generation was nonsignificant $(r=0.092, n=$ 80 ), and in the $F_{2}$ there was a weak but significant negative relationship ( $\left.r=-0.202^{* *}, n=200\right)$. The tendency toward a negative relationship between HCN$\mathrm{p}$ and $\mathrm{LAC}$ also was apparent in the backcross and $\mathrm{F}_{2}$ means (Table 1). In the backcross generation, the mean HCN-p value for the I-HCN-p, LAC+ class was 170 $\mathrm{mg} \mathrm{kg} \mathrm{kg}^{-1}$ compared to 222 for the I-HCN-p LACclass. Similarly, in the $F_{2}$ generation, means of 204 and $332 \mathrm{mg} \mathrm{kg} \mathrm{me}^{-1}$ were obtained for the I-HCN-p, $\mathrm{LAC}+$ and I-HCN-p, LAC - classes, respectively. Also, mean $H C N$-p values were higher and $A_{540}$ values were lower for the I-HCN-p, LAC + classes in both backcross (170 and 0.41$)$ and $F_{2}$ (204 and 0.64) generations than for the Colman parent (135 and 1.33). However, regardless of any effect LAC level might have had on HCN-p, the two major genes appeared to be inherited independently.

\section{Acknowledgments}

The excellent technical assistance of Carol A. Caha and John J. Toy is gratefully acknowledged, as is the contribution of Dr. A. Sotomayor-Rios, who produced the backcross and $F_{2}$ seed in Puerto Rico.

\section{References}

1. Gorz, H.J., F.A. Haskins, and K.P. Vogel. 1986. Inheritance of dhurrin content in mature sorghum leaves. Crop Sci. 26:65-67.

2. Haskins, F.A., and H.J. Gorz. 1986. Inheritance of leucoanthocyanidin content in sorghum leaves. Crop Sci. 26:286-288.

3. ---, and ---. 1986. Relationship between contents of leucoanthocyanidin and dhurrin in sorghum leaves. Theor. Appl. Genet. 73:2-3. 